\title{
REVIEW \\ Post-natal imprinting: evidence from marsupials
}

\author{
JM Stringer ${ }^{1,2,3}$, AJ Pask ${ }^{3,4}$, G Shaw $^{3}$ and MB Renfree ${ }^{3}$
}

Genomic imprinting has been identified in therian (eutherian and marsupial) mammals but not in prototherian (monotreme) mammals. Imprinting has an important role in optimising pre-natal nutrition and growth, and most imprinted genes are expressed and imprinted in the placenta and developing fetus. In marsupials, however, the placental attachment is short-lived, and most growth and development occurs post-natally, supported by a changing milk composition tailor-made for each stage of development. Therefore there is a much greater demand on marsupial females during post-natal lactation than during pre-natal placentation, so there may be greater selection for genomic imprinting in the mammary gland than in the short-lived placenta. Recent studies in the tammar wallaby confirm the presence of genomic imprinting in nutrient-regulatory genes in the adult mammary gland. This suggests that imprinting may influence infant post-natal growth via the mammary gland as it does pre-natally via the placenta. Similarly, an increasing number of imprinted genes have been implicated in regulating feeding and nurturing behaviour in both the adult and the developing neonate/offspring in mice. Together these studies provide evidence that genomic imprinting is critical for regulating growth and subsequently the survival of offspring not only pre-natally but also post-natally.

Heredity (2014) 113, 145-155; doi:10.1038/hdy.2014.10; published online 5 March 2014

\section{INTRODUCTION}

Genomic imprinting has been identified in all eutherian and marsupial species examined. Currently, about 150 autosomal and $\mathrm{X}$-linked imprinted genes have been identified in eutherians (Williamson et al., 2013). Of these, approximately 29 have been investigated in marsupials, excluding X-inactivation genes Xist (Davidow et al., 2007) and RSX (Grant et al., 2012). So far 8 have been confirmed to be imprinted, 13 are thought not to be imprinted and 8 genes appear to be absent from the marsupial genome (Pask, 2012; Renfree et al., 2013; Table 1). It should be noted that non-conventional, outbred animals models have significant limitations for imprinting analyses. Thus, some studies use non-quantitative methods to analyse imprinted gene expression, and many examine whole-organ homogenates in which different cell types may have imprinted and non-imprinted expression patterns that can lead to the erroneous conclusion that imprinted expression does not occur.

Although expression studies in monotremes are limited to two genes so far, insulin-like growth factor 2 and one of its receptors (IGF2 and IGF2R, respectively), additional bioinformatic analysis suggests that imprinting does not exist in the monotreme mammals (Pask et al., 2009; Renfree et al., 2009; Suzuki et al., 2011a). Thus, imprinting is presumed to have first evolved concurrently with viviparity in mammals (Renfree et al., 2013), after the divergence of the monotreme lineage from the therian mammals but before the divergence of eutherian and marsupial mammals around 160 million years ago (Luo et al., 2011). However, the only tissues tested for imprinting in monotremes have been the adult brain, intestine, liver, kidney and spleen (Killian et al., 2000, 2001; Edwards et al., 2007). In the mouse, for example, IGF2 expression in the adult is almost entirely restricted to the choroid plexus where it is biallelically expressed. Similarly, tammar IGF2 imprinting may be developmental age specific (Suzuki et al., 2005; Smits et al., 2008; Stringer et al., 2012b), as it is in humans (Issa et al., 1996; Li et al., 1998), so it remains possible that there are imprinted genes in monotremes.

Imprinting negates the advantages of diploidy by causing monoallelic gene expression, consequently increasing the chance of exposing deleterious mutations. Many hypotheses have been developed attempting to explain how and why imprinting evolved. However, no single theory can explain unequivocally the existence of imprinting at all loci, and imprinting may have evolved at different loci under different evolutionary pressures.

Marsupials such as the Australian tammar wallaby (Macropus eugenii) and the South American opossum (Monodelphis domestica) have proven to be useful comparative models in which to investigate the evolution and maintenance of imprinted genes (Pask, 2012; Graves and Renfree, 2013; Renfree et al., 2013). Analysis of the marsupial paternally expressed gene 10 (PEG10), the ubiquitinprotein ligase E3A (UBE3A)/small nuclear ribosnucleoprotein polypeptide $\mathrm{N}(S N R P N)$ region and growth factor receptor binding protein 10 (GRB10) supports the host-defence hypothesis for the acquisition of imprinting (for more information, see Renfree et al., 2009, 2013). The host-defence hypothesis proposes that therian

${ }^{1}$ Centre for Genetic Diseases, Monash Institute of Medical Research and Prince Henry's Institute, Clayton, Victoria, Australia; ${ }^{2}$ Faculty of Medicine, Nursing and Health Sciences, Monash University, Clayton, Victoria, Australia; ${ }^{3}$ Department of Zoology, The University of Melbourne, Melbourne, Victoria, Australia and ${ }^{4}$ Department of Molecular and Cellular Biology, The University of Connecticut, Storrs, CT, USA

Correspondence: Dr JM Stringer, Centre for Genetic Diseases, Monash Institute of Medical Research, 27-31 Wright Street, Clayton, Victoria 3168, Australia.

E-mail: Jessica.stringer@monash.edu

or Professor MB Renfree, Department of Zoology, The University of Melbourne, Melbourne, Victoria 3010, Australia.

E-mail: m.renfree@unimelb.edu.au

Received 4 September 2013; revised 19 December 2013; accepted 9 January 2014; published online 5 March 2014 
Table 1 Genes imprinted in eutherians that have been examined in marsupials

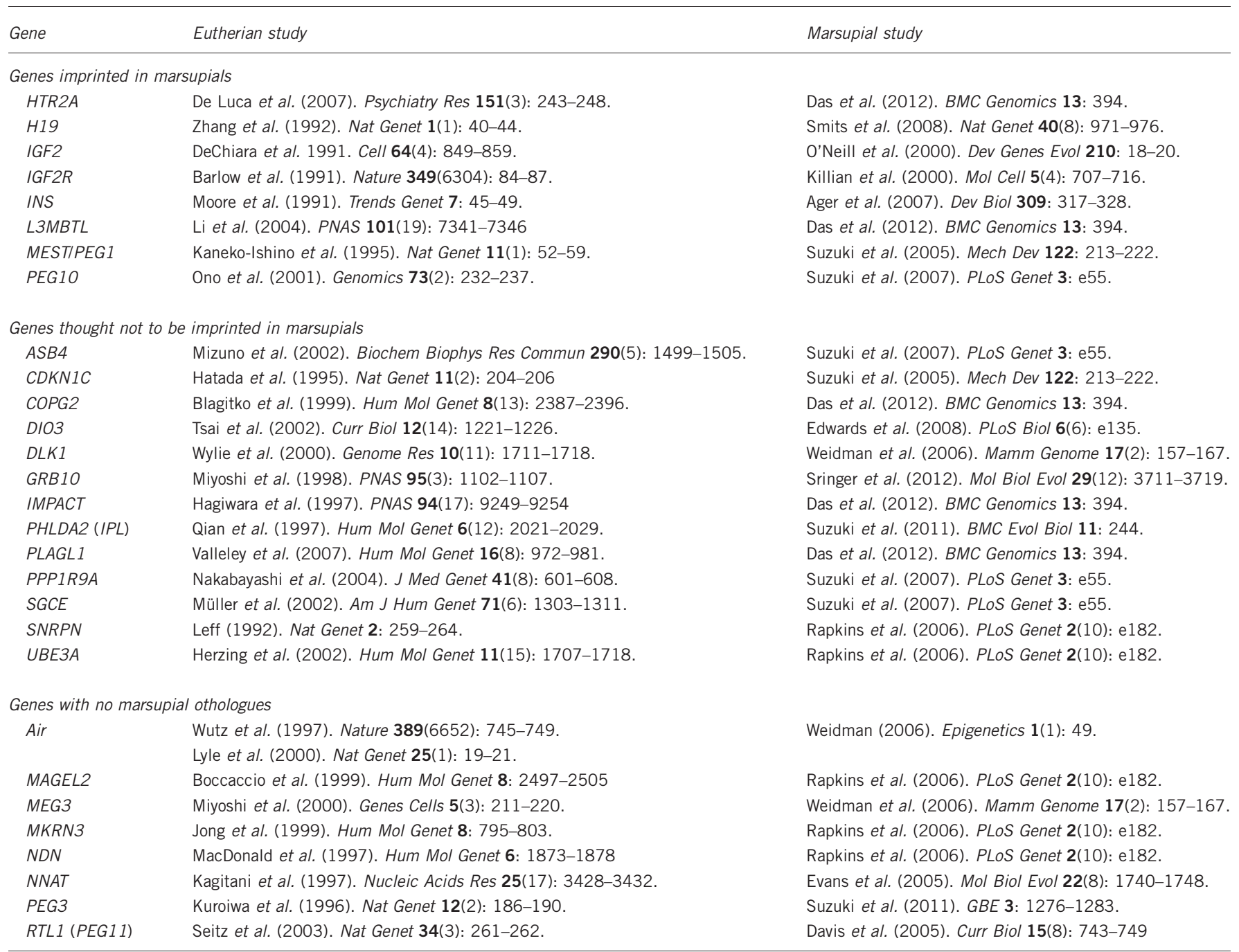

genomic imprinting mediated by differentially methylated regions (DMRs) could originate from the cellular mechanisms such as DNA methylation that evolved to repress exogenous DNA sequences inserted by retrotransposons (Chai et al., 2001; Rapkins et al., 2006; Suzuki et al., 2007; Stringer et al., 2012a). Such genome invasions occur continuously and stochastically and attract DNA methylation. If such insertions create or entrap a gene that confers a fitness advantage in the imprinted state, it can become fixed. Thus, the host-defence hypothesis attempts to explain how imprinting is established at a locus and is distinct from the kinship and co-adaptation hypothesis, which discuss the selective pressures that are required for maintaining imprinted gene expression after its acquisition.

The vast majority of studies of imprinting in eutherians have focused on embryonic development and placental function, as differentiation occurs during gestation. In eutherians, the birth weight is usually a high proportion of the maternal body weight-for example, offspring of humans, elephants and whales are approximately $3-5 \%$ of the mother's weight. In contrast, the altricial young of the tammar is $<0.1 \%$ (Table 2). Therefore there has been a greater selection pressure on a eutherian mother to provide nutrients during
Table 2 Gestation length and comparison of infant birth weight to maternal weight

\begin{tabular}{lccccc}
\hline & Elephant & Macaque & Pig & Rat & Tammar \\
\hline Maternal weight, kg & 2748.0 & 6.8 & 75.0 & 0.17 & 5 \\
Approximate birth weight & $120.0 \mathrm{~kg}$ & $0.54 \mathrm{~kg}$ & $1.45 \mathrm{~kg}$ & $5 \mathrm{~g}$ & $0.4 \mathrm{~g}$ \\
Average litter size & 1 & 1 & 4 & 7 & 1 \\
Duration of gestation (days) & 645.4 & 171.2 & 131.3 & 22.3 & 26.5 \\
Percentage of maternal weight & $4-5$ & $7-8$ & $7-8$ & $20-21$ & 0.01 \\
\hline
\end{tabular}

pregnancy than on a marsupial mother. In marsupials, the altricial neonate is tiny and is essentially an exteriorised fetus and the majority of growth occurs post-natally totally dependent on the supply of maternal milk through a long, complex and physiologically sophisticated period of lactation (Tyndale-Biscoe and Renfree, 1987; Renfree, 2010) (Figure 1). This review discusses recent studies investigating the acquisition of imprinted genes and genes with post-natal functions and relates this new information to the current theories on the evolution of imprinting. 


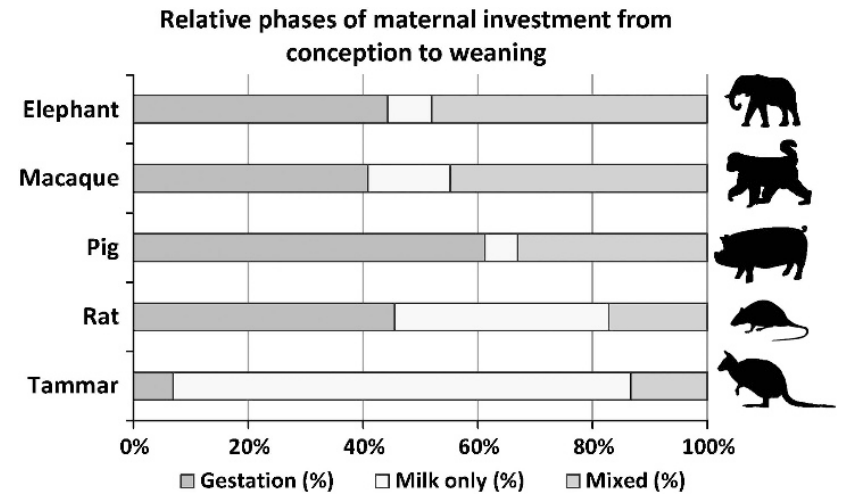

Figure 1 Relative phases of maternal investment from conception to weaning. The percentage of time spent during gestation, lactation (milk-only period) and mixed feeding (milk and solids) for elephants, macaques, pigs, rats (Langer, 2008) and tammar wallabies. There are four classes by which eutherians are grouped based on the characteristics of the young or litter at birth. Elephants represent group 4 and are described as precocial (open eyes and haired) and nidifugous (leaves the nest shortly after hatching or birth). Macaques represent group 3 and are described as precocial and transported (young are supported or carried). Pigs represent group 2 and are described as precocial and nidicolous (dependent on parent for feeding, care and protection). Rats represent group 1 and are described as altricial (closed eyes and naked) and nidicolous. Tammars are classified as altricial, nidicolous and transported, spending >270-300 days of the 350 days of lactation in the pouch totally dependent on milk. Also see Table 2 for gestation length in days.

\section{DIFFERENTIAL METHYLATION AS A CONSERVED MECHANISM OF IMPRINTED GENE REGULATION}

The majority of eutherian autosomal imprinted genes are marked by DNA methylation and histone modifications that differ between maternal and paternal alleles. However, the regulatory activities underlying these marks vary among loci. To regulate imprinting, parental-specific epigenetic modifications must be established in the germline, maintained throughout development and then erased before they are re-established in the host germline (reviewed in Saitou and Yamaji, 2010; Hackett et al., 2012; Saitou et al., 2012; Stringer et al., 2013). In eutherians, the majority of epigenetic reprogramming occurs in utero, with some de novo methylation occurring postpartum in the oocytes (Seisenberger et al., 2012; Tomizawa et al., 2012). In marsupials, germ cells are still proliferating postpartum and do not begin to enter meiosis (females) or mitotic arrest (males) until 25 days after birth (Ullmann et al., 1997; Renfree and Shaw, 2001). Nevertheless, the relative timing and mechanisms of germ cell reprogramming are conserved between eutherians and marsupials, suggesting that these mechanisms evolved well over 160 million years ago (Suzuki et al., 2013).

DMRs are associated with almost all eutherian imprinted gene clusters, but the presence of the DMR is not necessarily the sole epigenetic modification required for monoallelic expression. Other repressive epigenetic marks, such as histone modifications, are likely to have a significant role. In somatic cells, the methylated allele within an imprinting control region (ICR) is associated with repressive histone modifications, including $\mathrm{H} 4$ lysine 20 and $\mathrm{H} 3$ lysine 9 trimethylation (H4K20me3 and $\mathrm{H} 3 \mathrm{~K} 9 \mathrm{me} 3$ ), whereas the unmethylated allele is enriched for permissive histone modifications, such as H3K4me2 and acetylated H3 (H3ac) (Delaval et al., 2007). However, germline DMRs are the main epigenetic mark distinguishing parental alleles of imprinted genes in the early embryo. Thus far, only three DMRs have been identified in marsupials in the promoters of PEG10,

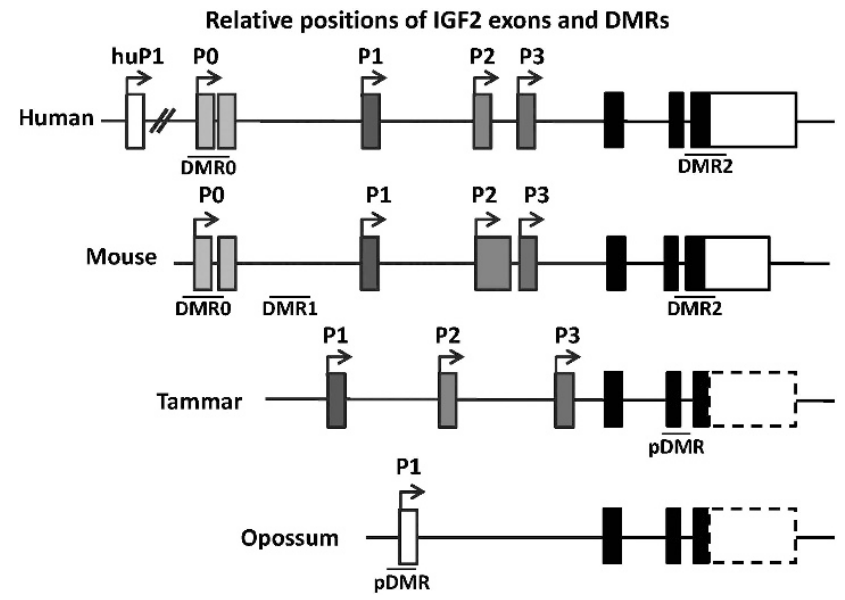

Figure 2 Comparative IGF2 gene structure. Schematic of human, mouse, tammar and opossum IGF2 (not to scale). Mouse has four promoters and three DMRs, while human has five promoters. There is no mouse homologue for human P1 (HuP1). The P0 promoters and non-coding exons are homologous to each other as are mouse P1-P3 to human P1-P3. Tammar has three promoters homologous to mouse and human P1-P3 and a putative DMR (pDMR) homologous to mouse and human DMR2. The opossum has one promoter and one non-coding exon and a putative DMR located at the transcription start site. The coding region of mammalian IGF2 is located in the last three exons (black boxes). Transcription start sites are indicated with turned arrows. Homologous non-coding exons are represented by coloured boxes: P0 (orange), P1 (blue), P2 (Red) and P3 (green); white boxes: non-homologous non-coding exons. A full color version of this figure is available at the Heredity journal online.

H19 and IGF2R (Suzuki et al., 2007; Smits et al., 2008; Das et al., 2012). An additional two putative DMRs have also been identified in IGF2 and INS (Lawton et al., 2008; Stringer et al., 2012b, c). The existence of homologous DMRs in both marsupials and eutherians suggests that, for some genes, genomic imprinting regulated by differential methylation evolved before the divergence of these mammal groups (Suzuki et al., 2007; Smits et al., 2008).

IGF2 was the first imprinted gene identified in eutherians and marsupials and encodes a growth-promoting gene that is maternally silenced in all therian species so far examined (DeChiara et al., 1991; O'Neill et al., 2000). Igf2 modulates both placental supply and fetal demand of nutrients (Constancia et al., 2002; Reik et al., 2003). Imprinting of IGF2 and INS in mice and humans is regulated by the H19/IGF2 ICR. The ICR is located approximately $2 \mathrm{~kb}$ upstream of H19 and contains several CpG sites and four highly conserved 11-zinc-finger nuclear protein (CTCF) binding sites (Bell and Felsenfeld, 2000; Hark et al., 2000; Kanduri et al., 2000; Szabo et al., 2004). There are several spatially and temporally regulated endoderm and mesoderm enhancers downstream of the $\mathrm{H} 19$ gene (Gabory et al., 2006). The binding of CTCF to the unmethylated maternal ICR blocks the interaction of the enhancers with the IGF2 promoters and silences the maternal allele. Methylation of the DMR on the paternal allele prevents CTCF protein binding, repressing the H19 promoter while allowing IGF2 expression. This ICR and DMR is highly conserved in marsupials, suggesting that DMR regulatory mechanisms arose in the therian ancestor (Smits et al., 2008).

Eutherian IGF2 has multiple promoters and transcription start sites adjoining distinct non-coding exons: four in rodents and five in humans (Figure 2) (Rotwein and Hall, 1990; Vu and Hoffman, 1994; Monk et al., 2006). The opossum neonate and the adult platypus produce only a single IGF2 transcript, and only one opossum 
non-coding exon has been identified (Killian et al., 2001; Lawton et al., 2008). Interestingly, tammar IGF2 has three promoters and non-coding exons, orthologous to the eutherian P1-P3. Additionally, a putative tissue-specific DMR, othologous to mouse and human DMR2 (Monk et al., 2006), was identified in the tammar placenta (Figure 2) (Stringer et al., 2012b). Opossum IGF2 also has a possible DMR, located at the single transcription start site, but it is not orthologous to either the mouse or human DMRs (Lawton et al., 2008). This suggests independent selection for DMR-associated silencing in two disparate lineages (Stringer et al., 2012b).

Human IGF2R has a DMR but lacks the parental promoter allelespecific histone modifications that are thought to regulate imprinted expression of mouse Igf2r. Hence, human IGF2R is biallelically expressed (Yang et al., 2003; Vu et al., 2004). In marsupials, IGF2R is imprinted and possesses a novel DMR not present in eutherian mammals (Das et al., 2012). Interestingly, there is an allele-specific permissive histone modification ( $\mathrm{H} 3 \mathrm{~K} 4 \mathrm{me} 2)$ at the IGF2R promoter (Das et al., 2012). Although the repressive mark H3K9me3 is absent, other modifications (for example, H3K27me3, H4K20me3) may be present and function to repress the paternal allele (Delaval et al., 2007; Henckel et al., 2009; Das et al., 2012). Therefore, some DMRs are conserved between marsupials and eutherians at some loci, while at other loci epigenetic mechanisms have clearly diverged between these groups.

\section{IMPRINTING IN THE MAMMARY GLAND}

The role of imprinted genes in pre-natal nutrient transfer and placental development is well established (Coan et al., 2005; Constancia et al., 2005; Renfree et al., 2013). However, there is comparatively little information on the possible role of imprinted genes in the provision of post-natal resources and care during lactation. Unlike the placenta, which contains fetal-derived cells with genetic contributions from both of the offspring's parents, the mammary gland is comprised purely of maternal cells. Therefore, only a matrilineal grandparental genetic contribution is regulating post-natal resource allocation.

In mouse mammary epithelial cells, $\mathrm{X}$-chromosome inactivation is not random but is preferentially maternally inactivated (Jiao et al., 2012). Interestingly, the $\mathrm{X}$-linked gene ring finger protein 12 (Rnf12), which encodes the ubiquitin ligase Rnf12/RLIM, is a critical survival factor for milk-producing alveolar cells (Jiao et al., 2012). In humans, limited studies of gene expression in the breast have similarly demonstrated monoallelic expression of growth and survival factors in normal breast tissues.

However, during breast cancer, there is mis-regulation of a number of monoallelic genes. Breast cancer is genetically heterogeneous, and a variety of genetic lesions have been identified that tend to accumulate during disease progression. Six genes, all with potential roles in cancer progression, are monoallelically expressed (presumed to be imprinted) in the mammary gland and show mis-expression in various breast cancers, namely, IGF2, H19, distinct subgroup of the RAS family (DIRAS3), mesoderm-specific transcript (MEST/PEG1), human MAS proto-oncogene and IGF2R (Yballe et al., 1996; Oates et al., 1998; Pedersen et al., 1999; Yu et al., 1999).

MEST is monoallelically expressed in normal breast tissue, so it may be imprinted and involved in the regulation of gland growth in humans (Pedersen et al., 1999). In the mouse, Mest is imprinted and paternally expressed in a variety of adult tissues, albeit at lower levels than the developing embryo (Reule et al., 1998; Takahashi et al., 2005). Mest appears to be involved in the formation of white adipose tissue, including the determination of adipose cell size (Takahashi et al., 2005). Interestingly, white adipose tissue is vital for the mammary gland development (Couldrey et al., 2002). Thus, Mest may be required for the development and function of the mammary gland in addition to its role in the hypothalamus. However, Mest expression has not yet been investigated in the mouse mammary gland, and the monoalleic expression in the human breast has not yet been attributed to genomic imprinting.

DIRAS3 (NOEY2/ARHI), a putative tumour-suppressor gene, is imprinted and paternally expressed in cultured human breast epithelial cells (Yu et al., 1999, 2003). Interestingly, DIRAS3 deletion (presumably paternally inherited) occurs in a substantial fraction of human breast cancers (Yu et al., 1999). Overexpression of a human DIRAS3 transgene in mice is associated with a decrease in body size, greatly impaired mammary gland development and lactation, decreased fertility, loss of neurons in the cerebellar cortex and impaired development of the thymus (Xu et al., 2000). Mas is a proto-oncogene maternally imprinted in mice in a highly developmental and tissue-specific manner (Villar and Pedersen, 1994). In mice, Mas is an important modulating factor in the electrophysiology of the hippocampus and is involved in behavioural pathways in the adult brain (Walther et al., 1998). In humans, MAS is biallelically expressed in the fetus (Riesewijk et al., 1996), but monoallelic expression has been detected in normal breast tissue (Miller et al., 1997). This indicates the possible presence of a functional imprint at this locus in humans, but this finding requires further investigation to see if it is truly a result of genomic imprinting.

In the tammar, lactation takes up to 9-10 months while the young increases from a birth weight of $450 \mathrm{mg}$ to $2.5 \mathrm{~kg}$ when they are fully weaned (Figure 1). Active pregnancy is $<1$ month in duration in the tammar, and gastrulation to birth is only about 10 days, so the energy transfer from mother to young is proportionately less than in eutherian mammals (Figure 1; Table 2). However, by the time of weaning and permanent pouch exit, the energy transfer from mother to young is roughly equivalent to that of a sheep to its newborn lamb (Cork and Dove, 1989). There are dramatic changes in milk volume, milk composition and individual milk constituents throughout marsupial lactation (Green, 1984). In contrast, apart from the initial production of colostrum $24-48 \mathrm{~h}$ postpartum, the composition of mature eutherian milk changes are not as dynamic and are speciesspecific (Oftedal and Iverson, 1995). There are three broad phases in marsupial lactation that reflect these changes (Figure 3). Phase 1 is the time during pregnancy when the mammary gland prepares for lactation; Phase 2 (Day 0-200) is the initiation of lactation and production of the early milk, which is characterised by the high carbohydrate-low fat content. During Phase 3 (days 200-350) fat content rises steadily, whereas carbohydrate levels fall (Tyndale-Biscoe and Renfree, 1987). In addition, there are tightly regulated changes in the specific proteins and amino acids during each phase (Renfree et al., 1981; Nicholas, 1988; Trott et al., 2003). Thus if imprinting was maintained to regulate maternal investment and nutrient transfer, the acquisition of imprinted genes in the mammary gland may be more important than those in the placenta to marsupials.

Insulin (INS) is a key gene required for carbohydrate metabolism, intra-uterine growth and the establishment of lactation. In mammals, insulin, in addition to cortisol and prolactin, is an absolute requirement for synthesis of milk (Menzies et al., 2010). In the tammar, insulin is a crucial requirement to stimulate milk-protein synthesis and establish lactation (Nicholas et al., 1991; Trott et al., 2002, 2005). In eutherians, INS has only been confirmed as imprinted in the yolk sac placenta (Deltour et al., 1995; Moore et al., 2001). In marsupials, INS is imprinted in the yolk sac placenta, but the maternal allele is not 


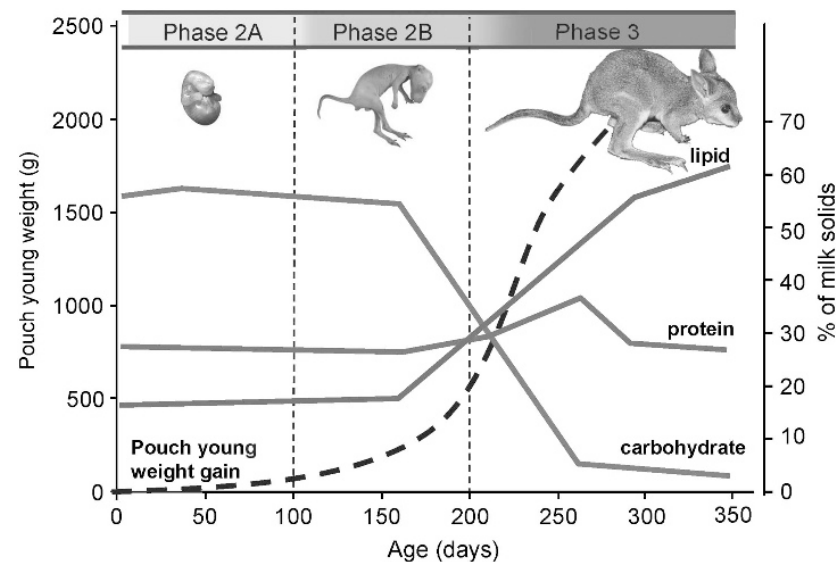

Figure 3 Milk composition and pouch young growth. Changes in protein, carbohydrate and fat content of milk (redrawn from Green, 1984). There are four stages of lactation in the tammar (Tyndale-Biscoe and Renfree, 1987). Phase 1 encompasses the initiation of lactogenesis in late gestation. Phase $2 \mathrm{~A}$ spans the first $100-125$ days of pouch life when the young is permanently attached to the teat, followed by Phase 2B to day 200 postpartum, when the young can relinquish the teat and sucking becomes more intermittent. Phases $2 \mathrm{~A}$ and $2 \mathrm{~B}$ are characterised by milk that is high in carbohydrate and low in fat. Phase 3 of lactation (days 200-350) includes the period of rapid growth of the young when it begins to exit the pouch and starts to eat grass, up until weaning. This phase is characterised by low-carbohydrate, high-fat milk. Growth curve data provided by Renfree and Shaw (unpublished data). A full color version of this figure is available at the Heredity journal online.

completely silenced in all individuals (Ager et al., 2007). Consistent with eutherians studies, INS is not imprinted in the marsupial pancreas (Ager et al., 2007). Further analysis identified an alternative INS transcript expressed in the liver and mammary gland but not in the pancreas (Stringer et al., 2012c). This transcript contained an exon derived from the neighbouring tyrosine hydroxylase gene $(\mathrm{TH})$ along with the two coding INS exons (Figure 4). Non-transcript-specific analysis identified that INS is monoallelically expressed and is likely to be imprinted in the marsupial post-natal liver and mammary gland (Stringer et al., 2012c). Preliminary transcript-specific sequencing data and the identification of a putative DMR at the TH-INS transcription start site in both liver and mammary gland suggests that both TH-INS and INS are imprinted (Stringer et al., 2012c). Although it is unknown whether the TH-INS transcript produces a functional protein in the marsupial, a similar chimeric transcript produced in the chicken does (Hernandez-Sanchez et al., 2006). However, it is possible that the TH-INS is a non-coding RNA, and transcription may provide an alternative mechanism to regulate INS expression. For example, TH-INS may be transcribed from the maternal allele and block INS transcription. Further analysis of the TH-INS and INS expression profiles and promoters is required to confirm this hypothesis (Figure 4).

IGF2 is a growth-promoting maternally imprinted gene (paternally expressed) in all therian species studied (DeChiara et al., 1991; Deltour et al., 1995; O'Neill et al., 2000). In the active mammary gland, IGF2 together with cyclin-D1 acts as a mediator of the prolactin-induced proliferation of mammary epithelial cells during alveolar formation (Brisken et al., 2002). Tammar IGF2 is imprinted and paternally expressed in the fetal and pouch young liver and has paternally biased biallelic expression in the whole placenta and pouch young brain (Suzuki et al., 2005; Smits et al., 2008). INS and IGF2 imprinting is regulated by the ICR, located between IGF2 and H19,

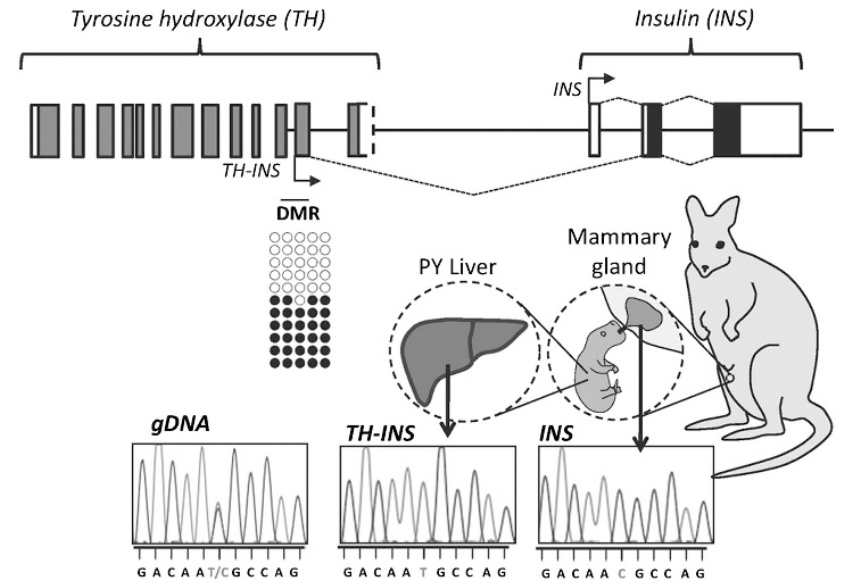

Figure 4 Schematic of predicted tammar TH and INS genes and the TH-INS and INS transcripts (not to scale). Predicted coding exons (grey), verified coding exons (black) and non-coding exons (white) are represented by boxes. Transcription start sites identified are indicated by turned arrows. The putative DMR is shown with individual bisulphite sequences underneath: open and closed circles are unmethylated and methylated CpGs, respectively. Each row represents the methylation pattern on a separate DNA fragment from the same sample. Both methylated and unmethylated alleles were present in the liver and mammary gland tissues at the TH-INS transcription start site. TH-INS and INS chromatogram traces (viewed in FinchTV version 5.1) for genomic DNA (gDNA) and complementary DNA (cDNA) derived from the pouch young liver and the adult mammary gland. The single-nucleotide polymorphism identified in the gDNA was used to determine monoallelic expression in the liver and mammary gland.

that is conserved in marsupials (Smits et al., 2008). Similar to INS, IGF2 is also monoallelically expressed in the adult mammary gland but not in the adult liver (Stringer et al., 2012b, c). As H19 is biallelically expressed in the liver (Smits et al., 2008), an alternative mechanism must be regulating TH-INS and INS monoallelic expression in this tissue. The observation of biallelic expression of IGF2 in the adult liver and clear monoallelic expression of both INS and IGF2 in the mammary gland strengthens the notion of a link between nutrient transfer and genomic imprinting (Stringer et al., 2012b).

\section{POST-NATALLY IMPRINTED GENES AND THE KINSHIP HYPOTHESIS}

Imprinted genes affect both the growth and transport capacity of organs involved in nutrient supply (for example, placenta) and modulate fetal requirements for nutrients, for example, by controlling fetal growth (Reik et al., 2003). Thus, the selective advantage of monoallelically expressing a gene in a population must outweigh the cost of an increased mortality rate. There are many hypotheses to explain the selective advantage that maintains genomic imprinting (Wilkins and Haig, 2003). The kinship (parental conflict) hypothesis is the most widely supported hypothesis, which predicts that parentspecific gene expression may be maintained to exploit the asymmetry in parental resource contribution to a given offspring (Haig and Westoby, 1989; Haig, 2004). In the offspring, expression of paternally inherited resource-acquisition genes are predicted to be modified to increase the growth of his offspring and to promote the extraction of the largest possible quantity of resources from its mother. This is of no fitness cost to the father, but the increase in size, fitness and reproductive success of his offspring increases his genetic fitness. Conversely, maternally expressed genes are predicted to reduce an 
individual offspring's resource demand so that she may provide for future offspring to maximise her reproductive fitness. Genomic imprinting is thought to have arisen as a result of this conflict. With regard to in utero resource allocation, the placenta is the most obvious site of conflict between parental genomes and is the main site of imprinted gene expression. Additionally, the pre-weaning stage of development is another potential conflict arena and recent studies have identified imprinted genes in the mother and the post-natal offspring that regulate the growth of the offspring.

Gnasxl is an imprinted gene, which is paternally expressed in key areas of the brain that innervate the facial and tongue muscles (Peters et al., 1999; Plagge et al., 2004). Deletion of this gene reduces the sucking behaviour of the newborn pups and results in substantially reduced milk intake and weight gain compared with wild-type littermates (Plagge et al., 2004). Gnasxl is therefore a post-natally imprinted gene that supports the kinship hypothesis for imprinting. The paternally inherited Gnasxl allele promotes milk intake, while the maternally inherited allele is silenced.

There are many imprinted genes with multiple functions; some of their functions are consistent with the predictions of the kinship hypothesis while others are harder to explain. Both Mest and Peg3 are paternally expressed and enhance fetal growth. In post-natal mice, these genes regulate pup attachment to the teat and sucking behaviour (Li et al., 1999; Curley et al., 2004). However, mutant females lack normal maternal behaviour such as placentophagia, retrieval of pups, nest building and normal suckling behaviour, which reduces survivability of her offspring. Maternal behaviour is not influenced by the offspring's father, and there is no obvious or direct conflict between grandparental genomes over the investment of the mother's resources. Therefore, the functions of Mest and Peg3 regulating maternal behaviour are inconsistent with the original kinship hypothesis. Although, some very minor asymmetries may occur if there is inbreeding in a population and if the degree of matrilineal vs patrilineal relatedness is skewed between a female and her mate (Wilkins and Haig, 2003). However, the selection from this minor asymmetry over maternal care is likely to be very weak and is unlikely to be the main selective force behind the evolution of imprinting at these loci (Wilkins and Haig, 2003).

Recent advances to the kinship theory define conditions for cooperation as well as conflict in mother-offspring relations, and imprinting of genes affecting maternal and communal care could have been driven by intragenomic conflict, distinct from parental conflict (Ubeda and Gardner, 2010, 2011; Haig, 2014). Further large-scale analyses of imprinted gene expression and function in the brain and other organs, such as the mammary gland and placenta, in a variety of social and 'anti-social' species are necessary to validate these predictions.

\section{THE CO-ADAPTATION HYPOTHESES}

An alternative hypothesis was proposed by Wolf and Hager (2006), called the maternal-offspring co-adaptation theory for the evolution of genomic imprinting (Wolf and Hager, 2006). They suggested that genes involved in the intimate maternal-offspring interaction are more likely to be maternally expressed as it enhances the genetic integration of these co-adapted traits. These traits are expected to be regulated by genes that are imprinted in the offspring but are biallelically expressed in the mother to increase their genetic relatedness. In support of this hypothesis, cross-fostered mice pups receive more provisioning from foster mothers of their own maternal strain irrespective of their father's strain (Hager and Johnstone, 2003).
The majority of imprinted genes are monoallelically expressed in the placenta. The placenta is a unique organ that not only controls pre-natal transfer of maternal resources but also ensures provision of these resources by regulating maternal food intake, maternal behaviour and metabolism. Through the production of hormones, the placenta primes the mother's brain in preparation for post-natal events to ensure mammary gland activation. Imprinted gene knockout mice result in an altered balance between placental and fetal growth and have highlighted the complex signalling used between the mother, placenta and fetus to optimise nutrient transfer (Godfrey et al., 1998; Angiolini et al., 2011; Kusinski et al., 2011; Burton and Fowden, 2012).

Keverne and Curley (2008) expanded the co-adaptation hypothesis to explain how paternally expressed imprinted genes have been maintained at some loci due to co-adaptation of the maternal hypothalamus and the placenta (Figure 5a) (Keverne, 1995; Constancia et al., 2005; Swaney et al., 2007; Keverne and Curley, 2008). In general, genes that are imprinted in the brain (more specifically, the hypothalamus) and the placenta are under matrilineal control. This means that the mother has silenced her own allele in her offspring, allowing the paternal allele to be expressed. As a male has the potential to sire more offspring than a female, paternal haploid expression of maternally imprinted genes have greater potential for rapid fixation of traits in the population. Such advantages rapidly establish homozygosity of a beneficial allele. When a placental/ hypothalamic maternally silenced gene is inherited from the father, both sons and daughters benefit from enhanced placental transfer, as well as the good 'communication' from the placenta to the mother's hypothalamus. When this gene is inherited from the mother, it is silenced, but her offspring benefit from good maternal care, increased maternal feeding and milk let-down through the action of the genes in the maternal hypothalamus. Her sons will produce offspring in the next generation expressing her allele, thereby escalating the co-adaptive advantages to the following generation.

The main concern for this adaption of the co-adaptation hypothesis is the inability to predict the direction of imprinting (Haig, 2014). Monoallelic expression of a maternal allele in the male should be disseminated as quickly as a paternally expressed allele; however, this allele would be silenced in his offspring. Instead, the offspring will express a maternal allele, which will increase the offspring's transcriptional relatedness to its mother. Wolf and Hager (2009) suggest that an advantage of resembling or not resembling a parent could favour the evolution of imprinted gene expression. This may, in part, be due to a transgenerational cis epistasis or the 'green-beard effect' (Haig, 1996, 2014). 'Green beard' refers to a gene that can 'recognise' their duplicate in another individual. In other words, if the mothers' responses (that is, nutrient provisioning, maternal care) are attuned to a particular stimulus provided by the offspring (that is, placental hormones, suckling, calling), then any offspring which inherit the genes that produce the required stimulus would receive more maternal resources than offspring that do not (Haig, 1996). Imprinting may allow the mother to 'selectively' invest more of her resources into offspring whose genome, which includes the paternal genomic contribution, appears to be more similar to her own. Thus the coadaptation hypothesis may be considered a type of kin selection that provides an explanation for the maintenance of imprinted genes in both the pre- and post-natal mammal. However, as Haig (2014) mentioned, if a gene's effects have a cost (trade-off) to either the parental or offspring fitness then genetic conflict will be present. It is very likely that a combination of the kinship, co-adaptation and phenotypic matching hypotheses resulted in the evolution of 


\section{a}

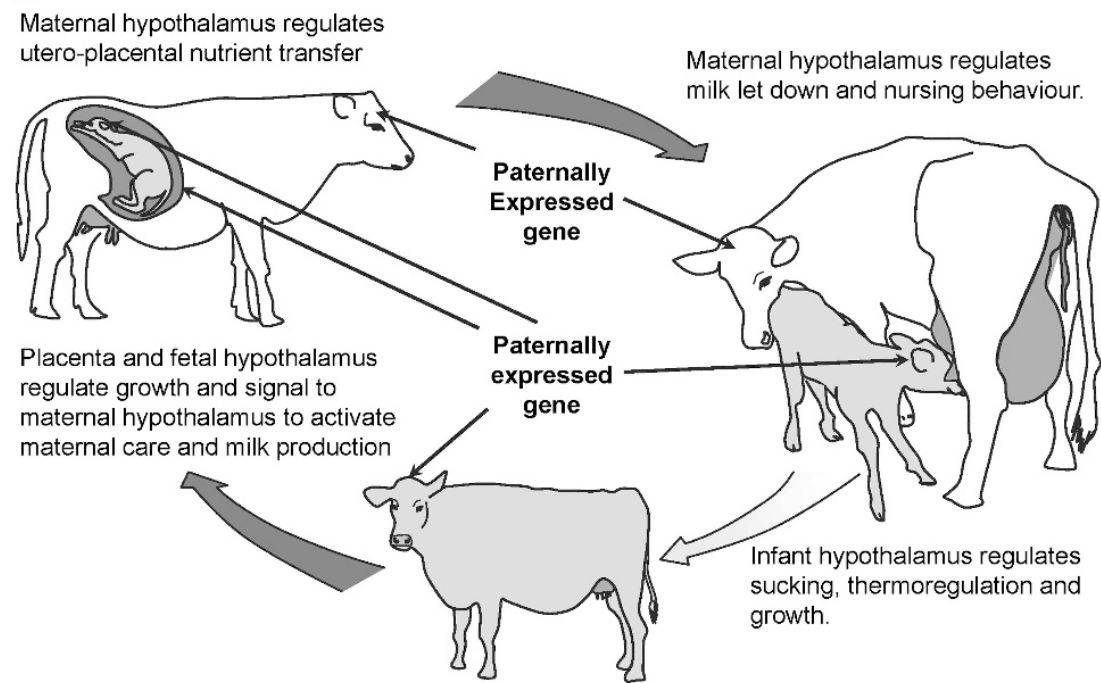

b

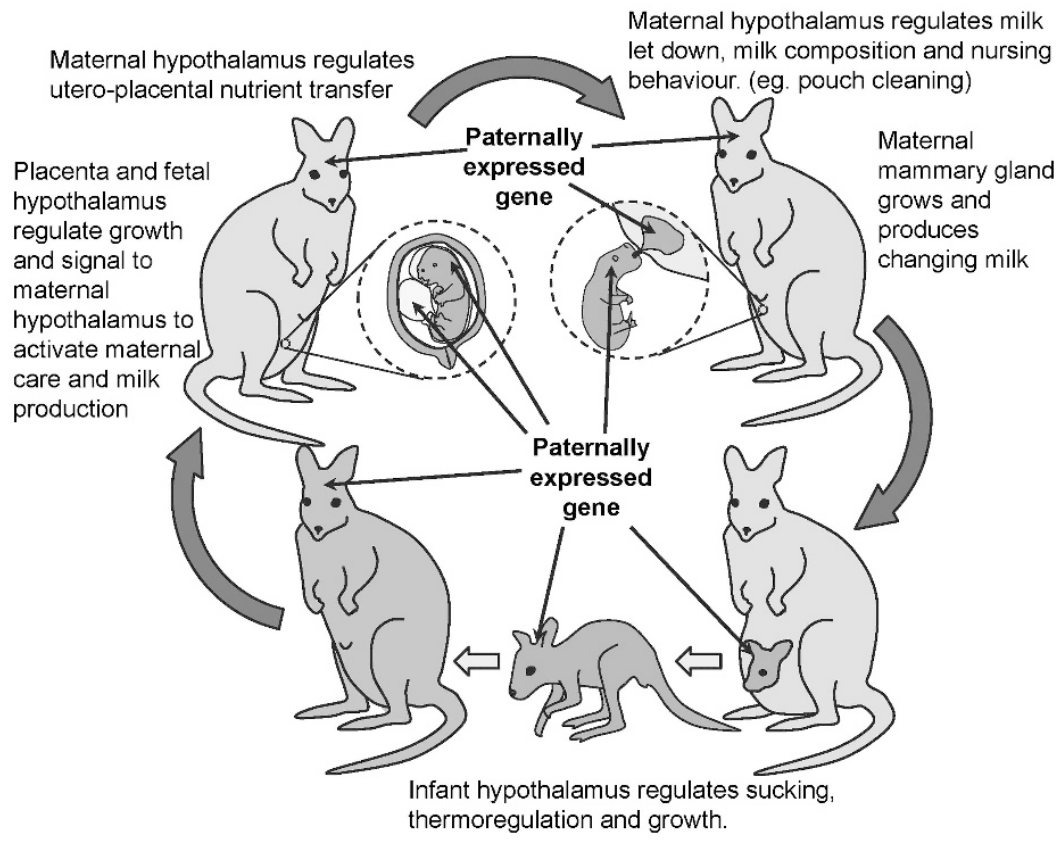

Figure 5 Maternal-infant co-adaptation. (a) Pre-natal and post-natal function of paternally expressed (maternally imprinted) genes in the hypothalamus and placenta in eutherians (adapted from Keverne and Curley (2008) and predicted functions (b) in the hypothalamus, placenta and mammary gland of marsupials.

imprinting and that it is dependent on gene location and function as to which combination of selective pressures resulted in imprinting. Defining such mechanisms requires an in-depth analysis of tissuespecific imprinting in addition to phylogenetic reconstructions to determine when, where and how imprinting arose in a particular locus.

The mammary gland is a unique mammalian organ that regulates post-natal nutritional transfer by a positive feedback loop with the mother's brain in response to the sucking stimulus. This interaction is similar to that observed between the placenta, fetus and the maternal hypothalamus (Figure 5b). Therefore, imprinting in the mammary gland may be the result of co-adaptation of the maternal and fetal genomes to enhance the genetic integration of the intimate maternaloffspring interactions. If the mammary gland is classed as a 'social organ', then imprinting may have been maintained in this organ due to intra-genomic conflict (Ubeda and Gardner, 2010, 2011; Haig, 2014). However, this selection is dependent on the skewed relatedness between siblings and individuals involved in communal care.

\section{THE EVOLUTION OF IMPRINTING IN THE POST-NATAL MAMMAL}

Peg3 provides an excellent example of an imprinted gene that supports the co-adaptation hypothesis for the evolution of genomic imprinting. $P e g 3$ is involved in maternal care, placental nutrient functions and regulating milk let-down. In addition, Peg3 confers olfactory advantages enabling male mice to distinguish between females in oestrus and di-oestrus (Keverne, 1995; Li et al., 1999; Curley et al., 2004). Peg3 also functions in the offspring's 
hypothalamus to regulate attachment to the teat and sucking behaviour (Li et al., 1999; Curley et al., 2004). Therefore, this gene would be dispersed quickly through a population when paternally expressed: male mice that are better able to identify oestrous females will sire more offspring that will receive and express this same beneficial allele. The offspring will receive adequate maternal provisioning both pre- and post-natally. Daughters will be genetically predisposed to become good mothers, while sons, like their father, acquire enhanced mating advantages (Keverne and Curley, 2008). Therefore, imprinted expression could be maintained in any organ that functions to regulate the growth and/or growth-influencing behaviour of the individual. The PEG3 gene contains 13 exons, the last 4 of which originated from the ancestral ZIM2 gene (Kim et al., 2000). PEG3 transcript encodes an unusual zinc finger protein with 11 widely spaced C2H2-like zinc finger motifs (Kuroiwa et al., 1996). It would be interesting to examine the expression and imprint status of the marsupial PEG3 gene in the marsupial brain, mammary gland and placenta. However, initial attempts to locate a PEG3 homologue in the marsupial genome have been confounded by the vast number of genes containing zinc finger motifs (Suzuki et al., 2011b).

IGF2 has an important role in development and brain function. Igf2 is imprinted in the rodent neonatal granule cells of the cerebellar parenchyma but not in the adult choroid plexus and leptomeninges (DeChiara et al., 1991; Pedone et al., 1994; Hetts et al., 1997). The expression in the granule cells has been associated with a role in cell proliferation and cerebellum weight during fetal and neonatal development (Hetts et al., 1997; Fernandez et al., 2010; Pidsley et al., 2012). In humans, IGF2 is monoallelically expressed within specific regions of the adult brain while it is biallelic in the fetal brain (Pham et al., 1998). Tammar IGF2 is imprinted in the placenta, fetal and pouch young liver and pouch young brain (Suzuki et al., 2005; Smits et al., 2008; Stringer et al., 2012b). Therefore, regionally restricted imprinting of IGF2 in the brain of human, mouse and tammar (Hetts et al., 1997; Suzuki et al., 2005; Smits et al., 2008; Stringer et al., 2012b) suggests that this pattern may have evolved in the therian ancestor. In the brain, IGF2 has been implicated in the regulation of brain morphology, food intake and in memory consolidation and enhancement (Lauterio et al., 1987; Ahmed and Lauterio, 1992; Hetts et al., 1997; Fernandez et al., 2010; Chen et al., 2011; Pidsley et al., 2012). In the adult rat, intracerebroventricular injection of IGF2 decreases food intake while injections into the hippocampus can significantly enhance memory retention. Both of these functions may have attracted imprinted gene expression based on both the kinship and co-adaptation models possibly as a mechanism to regulate gene dosage in the brain. Conditional lineage-specific knockouts of IGF2 in the rodent brain may identify the specific functions that attracted imprinted expression in certain brain compartments.

MAGE-like 2 gene (Magel2; a clock-controlled circadian output gene), like Mest and Peg3, is a paternally expressed gene in the hypothalamus. Adult mice deficient in Magel2 have markedly reduced activity, reduced metabolism, increased adiposity after weaning, behavioural problems and impaired male fertility (Bischof et al., 2007; Kozlov et al., 2007). Magel2-deficient mice have 50\% neonatal mortality with impaired suckling onset behaviour and subsequently impaired feeding (Schaller et al., 2010). Reduced oxytocin was also detected in the hypothalamus of Magel2 mutant neonates. An injection of oxytocin receptor antagonist replicated the Magel2 mutant feeding phenotype in wild-type neonates, and a single injection of oxytocin rescued the Magel2 mutant pup phenotype. Therefore, Magel2 is required for both milk let-down in the mothers and sucking behaviour in the neonates, which is regulated by paternally expressed imprinted genes in the hypothalamus, supporting the co-adaptation hypothesis.

GRB10 binds to the insulin and IGF1 receptors and possibly inhibits the growth-promoting and glucose homeostasis activities of insulin, IGF1 and IGF2 (Smith et al., 2007; O'Neill et al., 1996). Eutherian GRB10 transcription is regulated by two promoters, the maternally expressed major-promoter and a second paternally expressed brain-specific promoter. In the mouse, Grb10 is maternally expressed from the major-promoter in most tissues (Garfield et al., 2011). In humans, the expression of GRB10 from the major-promoter is biallelic in most tissues except in the placental villus trophoblasts in which it is maternally expressed (Hikichi et al., 2003; Monk et al., 2009). In the brain, Grb10 is paternally expressed from the brainspecific promoter within the diencephalon, ventral midbrain, medulla oblongata and along the ventral spinal cord (Garfield et al., 2011). However, although GRB10 is expressed in the marsupial brain, they do not have the brain-specific promoter (Stringer et al., 2012a). The expression from the tammar major-promoter is biallelic in a variety of adult and pouch young tissues, including the mammary gland. Therefore, imprinting at this locus evolved in eutherians after the eutherian-marsupial divergence and the emergence of a brain promoter, which may have occurred via the insertion of a parasitic DNA element (Stringer et al., 2012a).

In the mouse, disruption of the maternally expressed Grb10 transcript results in the overgrowth of both the embryo and the placenta (Charalambous et al., 2003; Charalambous et al., 2010). In the mammary epithelium, activation of signal transducer and activator of transcription 3 and 5 (STAT3 and STAT5, respectively) is sufficient to induce and suppress apoptosis, respectively (Clarkson et al., 2006). As Grb10 is a transcriptional target of Stat5a (Clarkson et al., 2006), its predicted function is to regulate the survival of mammary epithelial cells, promoting milk protein synthesis or release (Liu et al., 1997). Females who inherited a Grb10 deletion from their mothers have more pups, but these are smaller and the placental weight is significantly lower (Charalambous et al., 2010). Therefore, Grb10 may influence reproductive strategy through the allocation of maternal resources such that offspring number is offset against size. As GRB10 is a pleiotropic gene affecting maternal-offspring interactions, imprinting may have been maintained to increase the adaptive integration between the maternal and offspring genomes (Wolf and Hager, 2006). Further examination of the expression and function of imprinted genes in the eutherian mammary gland is required for a more complete understanding of why genes are imprinted. For example, the human major GRB10 promoter is thought to be maternally expressed only in the placenta. If this promoter is also imprinted in the human mammary epithelial cells, this would provide further evidence to support the co-adaptation hypothesis. Similarly, further comparisons of imprinted gene structure, expression and regulation between the three mammalian taxa will provide a clearer picture of how and when imprinting evolved at each locus.

\section{CONCLUDING REMARKS}

The reliance on a placenta during gestation and on lactation post parturition is a common and defining feature of eutherians, marsupials and monotremes. Viviparity has also evolved in fish and reptiles, especially squamates, that bear live young ones (Blackburn, 2006; Renfree et al., 2013). Therefore, if imprinting was maintained as a result of maternal-infant co-adaptation, then the mammary glands of monotremes and placentas of live-bearing reptiles would be prime targets for future investigation. In marsupials, infants are dependent 
on lactation for a much greater proportion of time, so it is perhaps not surprising that some imprinted genes may have been acquired in the mammary gland. Even in mice and humans, it is clear that there are an increasing number of imprinted genes identified in postnatal stages, so perhaps more imprinted genes will be identified in the mammary gland, some of which may be exclusively imprinted in this unique mammalian organ.

\section{CONFLICT OF INTEREST}

The authors declare no conflict of interest.

\section{ACKNOWLEDGEMENTS}

We thank our colleagues and students who have participated in our journey of discovery about genomic imprinting in marsupials. This work was supported by the Australian Research Council Centre of Excellence in Kangaroo Genomics. JMS is also supported by funding from the Monash University Faculty of Medicine, Nursing and Health Sciences and National Health and Medical Research Council funding (1043939 and 1051223) granted to Patrick Western and the Victorian Government's Operational Infrastructure Support Program.

Ager EI, Suzuki S, Pask AJ, Shaw G, Ishino F, Renfree MB (2007). Insulin is imprinted in the placenta of the marsupial, Macropus eugenii. Dev Biol 309: 317-328.

Ahmed I, Lauterio TJ (1992). Intracerebroventricular injection of insulin or glucose alters insulin-like growth factor II (IGF-II) concentrations in specific hypothalamic nuclei. Brain Res 595: 242-248.

Angiolini E, Coan PM, Sandovici I, Iwajomo OH, Peck G, Burton GJ et al. (2011). Developmental adaptations to increased fetal nutrient demand in mouse genetic models of Igf2-mediated overgrowth. FASEB J 25: 1737-1745.

Bell AC, Felsenfeld G (2000). Methylation of a CTCF-dependent boundary controls imprinted expression of the Igf2 gene. Nature 405: 482

Bischof JM, Stewart CL, Wevrick R (2007). Inactivation of the mouse Magel2 gene results in growth abnormalities similar to Prader-Willi syndrome. Hum Mol Genetics 16 2713-2719.

Blackburn D (2006). Squamate reptiles as model organisms for the evolution of viviparity. Herpetol Monogr 20: 131-146.

Brisken C, Ayyannan A, Nguyen C, Heineman A, Reinhardt F, Jan T et al. (2002). IGF-2 is a mediator of prolactin-induced morphogenesis in the breast. Dev Cell 3: 877-887.

Burton GJ, Fowden AL (2012). Review: The placenta and developmental programming: balancing fetal nutrient demands with maternal resource allocation. Placenta $\mathbf{3 3}$ S23-S27.

Chai J-H, Locke DP, Ohta T, Greally JM, Nicholls RD (2001). Retrotransposed genes such as Frat3 in the mouse chromosome 7C Prader-Willi syndrome region acquire the imprinted status of their insertion site. Mamm Genome 12: 813-821.

Charalambous M, Cowley M, Geoghegan F, Smith FM, Radford EJ, Marlow BP et al. (2010). Maternally-inherited Grb10 reduces placental size and efficiency. Dev Biol 337: 1-8.

Charalambous M, Smith FM, Bennett WR, Crew TE, Mackenzie F, Ward A (2003). Disruption of the imprinted Grb10 gene leads to disproportionate overgrowth by an lgf2-independent mechanism. Proc Natl Acad Sci USA 100: 8292-8297.

Chen DY, Stern SA, Garcia-Osta A, Saunier-Rebori B, Pollonini G, Bambah-Mukku D et al. (2011). A critical role for IGF-II in memory consolidation and enhancement. Nature 469: 491-497.

Clarkson RW, Boland MP, Kritikou EA, Lee JM, Freeman TC, Tiffen PG et al. (2006). The genes induced by signal transducer and activators of transcription (STAT) 3 and STAT5 in mammary epithelial cells define the roles of these STATs in mammary development. Mol Endocrinol 20: 675-685.

Coan PM, Burton GJ, Ferguson-Smith AC (2005). Imprinted genes in the placenta-A review. Placenta 26: S10-S20.

Constancia M, Angiolini E, Sandovici I, Smith P, Smith R, Kelsey G et al. (2005). Adaptation of nutrient supply to fetal demand in the mouse involves interaction between the Igf2 gene and placental transporter systems. Proc Natl Acad Sci USA 102: 19219-19224.

Constancia M, Hemberger M, Hughes J, Dean W, Ferguson-Smith A, Fundele R et al. (2002). Placental-specific IGF-II is a major modulator of placental and fetal growth. Nature 417: 945-948.

Cork SJ, Dove H (1989). Lactation in the tammar wallaby (Macropus eugenii). II. Intake of milk components and maternal allocation of energy. J Zool 219: 399-409.

Couldrey C, Moitra J, Vinson C, Anver M, Nagashima K, Green J (2002). Adipose tissue: a vital in vivo role in mammary gland development but not differentiation. Dev Dyn 223 459-468.

Curley JP, Barton S, Surani A, Keverne EB (2004). Coadaptation in mother and infant regulated by a paternally expressed imprinted gene. Proc $R \operatorname{Soc} A$ 271: 1303-1309.
Das R, Anderson N, Koran MI, Weidman JR, Mikkelsen TS, Kamal M et al. (2012). Convergent and divergent evolution of genomic imprinting in the marsupial Monodelphis domestica. BMC Genomics 13: 394.

Davidow L, Breen M, Duke S, Samollow P, McCarrey J, Lee J (2007). The search for a marsupial XIC reveals a break with vertebrate synteny. Chromosome Res 15: 137-146.

DeChiara TM, Robertson EJ, Efstratiadis A (1991). Parental imprinting of the mouse insulin-like growth factor II gene. Cell 64: 849-859.

Delaval K, Govin J, Cerqueira F, Rousseaux S, Khochbin S, Feil R (2007). Differential histone modifications mark mouse imprinting control regions during spermatogenesis. EMBO J 26: 720-729.

Deltour L, Montagutelli X, Guenet J-L, Jami J, Páldi A (1995). Tissue- and developmental stage-specific imprinting of the mouse proinsulin gene, Ins2. Dev Biol 168: 686-688.

Edwards CA, Rens W, Clarke O, Mungall AJ, Hore T, Graves JA et al. (2007). The evolution of imprinting: chromosomal mapping of orthologues of mammalian imprinted domains in monotreme and marsupial mammals. BMC Evol Biol 7: 157.

Fernandez C, Tatard VM, Bertrand N, Dahmane N (2010). Differential modulation of Sonic-hedgehog-induced cerebellar granule cell precursor proliferation by the IGF signaling network. Dev Neurosci 32: 59-70.

Gabory A, Ripoche MA, Yoshimizu T, Dandolo L (2006). The H19 gene: regulation and function of a non-coding RNA. Cytogenet Genome Res 113: 188-193.

Garfield AS, Cowley M, Smith FM, Moorwood K, Stewart-Cox JE, Gilroy K et al. (2011). Distinct physiological and behavioural functions for parental alleles of imprinted Grb10. Nature 469: 534-538.

Godfrey KM, Matthews N, Glazier J, Jackson A, Wilman C, Sibley CP (1998). Neutral amino acid uptake by the microvillous plasma membrane of the human placenta is inversely related to fetal size at birth in normal pregnancy. J Clin Endocrinol Metab 83: 3320-3326

Grant J, Mahadevaiah SK, Khil P, Sangrithi MN, Royo H, Duckworth J et al. (2012). Rsx is a metatherian RNA with Xist-like properties in X-chromosome inactivation. Nature 487 254-258.

Green B (1984). Composition of milk and energetics of growth in marsupials. Symp Zool Soc Lond 51: 369-387.

Graves JA, Renfree MB (2013). Marsupials in the age of genomics. Annu Rev Genomics Hum Genet 14:1 393-420.

Hackett JA, Zylicz JJ, Surani MA (2012). Parallel mechanisms of epigenetic reprogramming in the germline. Trends Genet 28: 164-174.

Hager R, Johnstone RA (2003). The genetic basis of family conflict resolution in mice. Nature 421: 533-535.

Haig D (1996). Gestational drive and the green-bearded placenta. Proc Natl Acad Sci USA 93: 6547-6551.

Haig D (2004). Genomic imprinting and kinship: how good is the evidence. Annu Rev Genet 38: 553-585.

Haig D, Westoby M (1989). Parent-specific gene expression and the triploid endosperm. Am Nat 134: 147-155

Haig D (2014). Coadaptation and conflict, misconception and muddle, in the evolution of genomic imprinting. Heredity 113: 96-103.

Hark AT, Schoenherr CJ, Katz DJ, Ingram RS, Levorse JM, Tilghman SM (2000). CTCF mediates methylation-sensitive enhancer-blocking activity at the H19/lgf2 locus. Nature 405: 486-489.

Henckel A, Nakabayashi K, Sanz LA, Feil R, Hata K, Arnaud P (2009). Histone methylation is mechanistically linked to DNA methylation at imprinting control regions in mammals. Hum Mol Genet 18: 3375-3383.

Hernandez-Sanchez C, Bartulos O, Valenciano AI, Mansilla A, de Pablo F (2006). The regulated expression of chimeric tyrosine hydroxylase-insulin transcripts during early development. Nucl Acids Res 34: 3455-3464.

Hetts SW, Rosen KM, Dikkes P, Villa-Komaroff L, Mozell RL (1997). Expression and imprinting of the insulin-like growth factor II gene in neonatal mouse cerebellum. J Neurosci Res 50: 958-966.

Hikichi T, Kohda T, Kaneko-Ishino T, Ishino F (2003). Imprinting regulation of the murine Meg1/Grb10 and human GRB10 genes; roles of brain-specific promoters and mousespecific CTCF-binding sites. Nucleic Acids Res 31: 1398-1406.

Issa JP, Vertino PM, Boehm CD, Newsham IF, Baylin SB (1996). Switch from monoallelic to biallelic human IGF2 promoter methylation during aging and carcinogenesis. Proc Natl Acad Sci USA 93: 11757-11762.

Jiao B, Ma H, Shokhirev MN, Drung A, Yang Q, Shin J et al. (2012). Paternal RLIM/Rnf12 is a survival factor for milk-producing alveolar cells. Cell 149: 630-641.

Kanduri C, Pant V, Loukinov D, Pugacheva E, Qi C-F, Wolffe A et al. (2000). Functional association of CTCF with the insulator upstream of the $\mathrm{H} 19$ gene is parent of originspecific and methylation-sensitive. Curr Biol 10: 853-856.

Keverne EB (1995). Olfactory learning. Curr Opin Neurobiol 5: 482-488.

Keverne EB, Curley JP (2008). Epigenetics, brain evolution and behaviour. Front Neuroendocrinol 29: 398-412.

Killian JK, Byrd JC, Jirtle JV, Munday BL, Stoskopf MK, MacDonald RG et al. (2000). M6P/IGF2R imprinting evolution in mammals. Mol Cell 5: 707-716.

Killian JK, Nolan CM, Stewart N, Munday BL, Andersen NA, Nicol S et al. (2001). Monotreme IGF2 expression and ancestral origin of genomic imprinting. J Exp Zool 291: 205-212.

Kim J, Bergmann A, Stubbs L (2000). Exon sharing of a novel human zinc-finger gene, ZIM2, and paternally expressed gene 3 (PEG3). Genomics 64: 114-118.

Kozlov SV, Bogenpohl JW, Howell MP, Wevrick R, Panda S, Hogenesch JB et al. (2007). The imprinted gene Magel2 regulates normal circadian output. Nat Genet 39: 1266-1272. 
Kuroiwa Y, Kaneko-Ishino T, Kagitani F, Kohda T, Li LL, Tada M et al. (1996). Peg3 imprinted gene on proximal chromosome 7 encodes for a zinc finger protein. Nat Genet 12: $186-190$.

Kusinski LC, Dilworth MR, Baker PN, Sibley CP, Wareing M, Glazier JD (2011). System A activity and vascular function in the placental-specific lgf2 knockout mouse. Placenta 32: 871-876

Langer $P$ (2008). The phases of maternal investment in eutherian mammals. Zoology (Jena) 111: 148-162

Lauterio TJ, Marson L, Daughaday WH, Baile CA (1987). Evidence for the role of insulinlike growth factor II (IGF-II) in the control of food intake. Physiol Behav 40: 755-758.

Lawton B, Carone B, Obergfell C, Ferreri G, Gondolphi C, VandeBerg J et al. (2008). Genomic imprinting of IGF2 in marsupials is methylation dependent. BMC Genomics 9: 205.

Li L, Keverne EB, Aparicio SA, Ishino F, Barton SC, Surani MA (1999). Regulation of maternal behavior and offspring growth by paternally expressed Peg3. Science 284: 330-333.

Li X, Gray SG, Flam F, Pietsch T, Ekstrm TJ (1998). Developmental-dependent DNA methylation of the IGF2 and H19 promoters is correlated to the promoter activities in human liver development. Int J Dev Biol 42: 687-693.

Liu X, Robinson GW, Wagner KU, Garrett L, Wynshaw-Boris A, Hennighausen L (1997). Stat5a is mandatory for adult mammary gland development and lactogenesis. Genes Dev 11: 179-186.

Luo ZX, Yuan CX, Meng QJ, Ji Q (2011). A Jurassic eutherian mammal and divergence of marsupials and placentals. Nature 476: 442-445.

Menzies K, Lee H, Lefèvre C, Ormandy C, Macmillan K, Nicholas K (2010). Insulin, a key regulator of hormone responsive milk protein synthesis during lactogenesis in murine mammary explants. Funct Integr Genomics 10: 87-95.

Miller N, McCann AH, O'Connell D, Pedersen IS, Spiers V, Gorey T et al. (1997). The MAS proto-oncogene is imprinted in human breast tissue. Genomics 46: 509-512.

Monk D, Arnaud P, Frost J, Hills FA, Stanier P, Feil R et al. (2009). Reciprocal imprinting of human GRB10 in placental trophoblast and brain: evolutionary conservation of reversed allelic expression. Hum Mol Genet 18: 3066-3074.

Monk D, Sanches R, Arnaud P, Apostolidou S, Hills FA, Abu-Amero S et al. (2006). Imprinting of IGF2 PO transcript and novel alternatively spliced INS-IGF2 isoform show differences between mouse and human. Hum Mol Genet 15: 1259-1269.

Moore GE, Abu-Amero SN, Bell G, Wakeling EL, Kingsnorth A, Stanier P et al. (2001). Evidence that insulin is imprinted in the human yolk sac. Diabetes 50: 199-203.

Nicholas KR (1988). Asynchronous dual lactation in a marsupial, the tammar wallaby (Macropus eugenii). Biochem Biophys Res Commun 154: 529-536.

Nicholas KR, Collet C, Joseph R, Sankaran L (1991). Hormone-responsive survival of mammary gland explants from the pregnant tammar wallaby (Mactopus eugenii) in the absence of exogenous hormones and growth factors. Comp Biochem Physiol 100 $163-167$.

O'Neill MJ, Ingram RS, Vrana PB, Tilghman SM (2000). Allelic expression of IGF2 in marsupials and birds. Dev Genes Evol 210: 18-20.

O'Neill TJ, Rose DW, Pillay TS, Hotta K, Olefsky JM, Gustafson TA (1996). Interaction of GRB-IR splice variant (a human GRB10 homolog) with the insulin and insulin-like growth factor I receptors. Evidence for a role in mitogenic signaling. J Biol Chem 271 $22506-22513$

Oates AJ, Schumaker LM, Jenkins SB, Pearce AA, DaCosta SA, Arun B et al. (1998). The mannose 6-phosphate/insulin-like growth factor 2 receptor (M6P/IGF2R), a putative breast tumor suppressor gene. Breast Cancer Res Treat 47: 269-281.

Oftedal OT, Iverson SJ (1995). Comparative analysis of nonhuman milks. A. Phylogenetic variation in the gross composition of milks. In: Jensen RG (ed.). Handbook of Milk Composition. Academic Press: San Diego, CA, USA. pp 749-780.

Pask A (2012). Insights on imprinting from beyond mice and men. Methods Mol Biol 925 263-275.

Pask AJ, Papenfuss AT, Ager EI, McColl KA, Speed TP, Renfree MB (2009). Analysis of the platypus genome suggests a transposon origin for mammalian imprinting. Genome Biol 10: R1

Pedersen IS, Dervan PA, Broderick D, Harrison M, Miller N, Delany E et al. (1999). Frequent loss of imprinting of PEG1/MEST in invasive breast cancer. Cancer Res 59 5449-5451.

Pedone PV, Cosma MP, Ungaro P, Colantuoni V, Bruni CB, Zarrilli R et al. (1994). Parental imprinting of rat insulin-like growth factor II gene promoters is coordinately regulated. J Biol Chem 269: 23970-23975.

Peters J, Wroe SF, Wells CA, Miller HJ, Bodle D, Beechey CV et al. (1999). A cluster of oppositely imprinted transcripts at the Gnas locus in the distal imprinting region of mouse chromosome 2. Proc Natl Acad Sci USA 96: 3830-3835.

Pham NV, Nguyen MT, Hu J-F, Vu TH, Hoffman AR (1998). Dissociation of IGF2 and H19 imprinting in human brain. Brain Res 810: 1-8.

Pidsley R, Dempster E, Troakes C, Al-Sarraj S, Mill J (2012). Epigenetic and genetic variation at the IGF2/H19 imprinting control region on $11 \mathrm{p} 15.5$ is associated with cerebellum weight. Epigenetics 7: 155-163.

Plagge A, Gordon E, Dean W, Boiani R, Cinti S, Peters J et al. (2004). The imprinted signaling protein $\mathrm{XL}$ alpha $\mathrm{s}$ is required for postnatal adaptation to feeding. Nat Genet 36: 818-826.

Rapkins RW, Hore T, Smithwick M, Ager E, Pask AJ, Renfree MB et al. (2006). Recent assembly of an imprinted domain from non-imprinted components. PLoS Genet 2: e182.

Reik W, Constancia M, Fowden A, Anderson N, Dean W, Ferguson-Smith A et al. (2003). Regulation of supply and demand for maternal nutrients in mammals by imprinted genes. J Physiol 547: 35-44.

Renfree MB (2010). Marsupials: placental mammals with a difference. Placenta 31 S21-S26.
Renfree MB, Meier P, Teng C, Battaglia FC (1981). Relationship between amino acid intake and accretion in a marsupial, Macropus eugenii. Neonatology 40: 29-37.

Renfree MB, Papenfuss AT, Shaw G, Pask AJ (2009). Eggs, embryos and the evolution of imprinting: insights from the platypus genome. Reprod Fertil Dev 21: 935-942.

Renfree MB, Shaw G (2001). Germ cells, gonads and sex reversal in marsupials. Int J Dev Biol 45: 557-567.

Renfree MB, Suzuki S, Kaneko-Ishino T (2013). The origin and evolution of genomic imprinting and viviparity in mammals. Philos Trans R Soc Lond B Biol Sci 368 20120151.

Reule M, Krause R, Hemberger M, Fundele R (1998). Analysis of Peg1/Mest imprinting in the mouse. Dev Genes Evol 208: 161-163.

Riesewijk AM, Schepens MT, Mariman EM, Ropers H-H, Kalscheuer VM (1996). The MAS proto-oncogene is not imprinted in humans. Genomics 35: 380-382.

Rotwein P, Hall LJ (1990). Evolution of insulin-like growth factor II: characterization of the mouse IGF-II gene and identification of two pseudo-exons. DNA Cell Biol 9: 725-735.

Saitou M, Kagiwada S, Kurimoto K (2012). Epigenetic reprogramming in mouse pre-implantation development and primordial germ cells. Development 139: 15-31.

Saitou M, Yamaji M (2010). Germ cell specification in mice: signaling, transcription regulation, and epigenetic consequences. Reproduction 139: 931-942.

Schaller F, Watrin F, Sturny R, Massacrier A, Szepetowski P, Muscatelli F (2010). A single postnatal injection of oxytocin rescues the lethal feeding behaviour in mouse newborns deficient for the imprinted Magel2 gene. Hum Mol Genet 19: 4895-4905.

Seisenberger S, Andrews S, Krueger F, Arand J, Walter J, Santos F et al. (2012). The dynamics of genome-wide DNA methylation reprogramming in mouse primordial germ cells. Mol Cell 48: 849-862

Smith FM, Holt LJ, Garfield AS, Charalambous M, Koumanov F, Perry M et al. (2007) Mice with a disruption of the imprinted Grb10 gene exhibit altered body composition, glucose homeostasis, and insulin signaling during postnatal life. Mol Cell Biol 27 5871-5886.

Smits G, Mungall AJ, Griffiths-Jones S, Smith P, Beury D, Matthews L et al. (2008). Conservation of the H19 noncoding RNA and H19-IGF2 imprinting mechanism in therians. Nat Genet 40: 971-976.

Stringer J, Barrand S, Western P (2013). Fine-tuning evolution: germ-line epigenetics and inheritance. Reproduction 146: R37-R48.

Stringer JM, Suzuki S, Pask AJ, Shaw G, Renfree MB (2012a). GRB10 imprinting is eutherian mammal specific. Mol Biol Evol 29: 3711-3719.

Stringer JM, Suzuki S, Pask AJ, Shaw G, Renfree MB (2012b). Promoter-specific expression and imprint status of marsupial IGF2. PLoS One 7: e41690.

Stringer JM, Suzuki S, Pask AJ, Shaw G, Renfree MB (2012c). Selected imprinting of INS in the marsupial. Epigenetics Chromatin 5: 14

Suzuki S, Ono R, Narita T, Pask AJ, Shaw G, Wang C et al. (2007). Retrotransposon silencing by DNA methylation can drive mammalian genomic imprinting. PLoS Genet 3: e55.

Suzuki S, Renfree MB, Pask AJ, Shaw G, Kobayashi S, Kohda T et al. (2005). Genomic imprinting of IGF2, p57 (KIP2) and PEG1/MEST in a marsupial, the tammar wallaby. Mech Dev 122: 213-222.

Suzuki S, Shaw G, Kaneko-Ishino T, Ishino F, Renfree MB (2011a). Characterisation of marsupial PHLDA2 reveals eutherian specific acquisition of imprinting. BMC Evol Biol 11: 244 .

Suzuki S, Shaw G, Kaneko-Ishino T, Ishino F, Renfree MB (2011b). The evolution of mammalian genomic imprinting was accompanied by the acquisition of novel $\mathrm{CpG}$ islands. Genome Biol Evol 3: 1276-1283.

Suzuki S, Shaw G, Renfree MB (2013). Postnatal epigenetic reprogramming in the germline of a marsupial, the tammar wallaby. Epigenetics Chromatin 6: 14 .

Swaney WT, Curley JP, Champagne FA, Keverne EB (2007). Genomic imprinting mediates sexual experience-dependent olfactory learning in male mice. Proc Natl Acad Sci USA 104: 6084-6089.

Szabo PE, Tang S-HE, Silva FJ, Tsark WMK, Mann JR (2004). Role of CTCF binding sites in the Igf2/H19 imprinting control region. Mol Cell Biol 24: 4791-4800.

Takahashi M, Kamei Y, Ezaki O (2005). Mest/Peg1 imprinted gene enlarges adipocytes and is a marker of adipocyte size. Am J Physiol Endocrinol Metab 288: E117-E124.

Tomizawa S, Nowacka-Woszuk J, Kelsey G (2012). DNA methylation establishment during oocyte growth: mechanisms and significance. Int J Dev Biol 56: 867-875.

Trott JF, Adams TE, Wilson M, Nicholas KR (2005). Positive and negative regulatory elements in the late lactation protein-A gene promoter from the tammar wallaby (Macropus eugenii). Biochim Biophys Acta 1728: 65-76.

Trott JF, Simpson KJ, Moyle RL, Hearn CM, Shaw G, Nicholas KR et al. (2003). Maternal regulation of milk composition, milk production, and pouch young development during lactation in the tammar wallaby (Macropus eugenii). Biol Reprod 68: 929.

Trott JF, Wilson MJ, Hovey RC, Shaw DC, Nicholas KR (2002). Expression of novel lipocalin-like milk protein gene is developmentally-regulated during lactation in the tammar wallaby, Macropus eugenii. Gene 283: 287-297.

Tyndale-Biscoe H, Renfree M (1987). Reproductive Physiology of Marsupials. Cambridge University Press. pp 476.

Ubeda F, Gardner A (2010). A model for genomic imprinting in the social brain: juveniles. Evolution 64: 2587-2600.

Ubeda F, Gardner A (2011). A model for genomic imprinting in the social brain: adults. Evolution 65: 462-475.

Ullmann SL, Shaw G, Alcorn GT, Renfree MB (1997). Migration of primordial germ cells to the developing gonadal ridges in the tammar wallaby Macropus eugenii. J Reprod Ferti 110: $135-143$.

Villar AJ, Pedersen RA (1994). Parental imprinting of the Mas protooncogene in mouse Nat Genet 8: 373-379. 
Vu TH, Hoffman AR (1994). Promoter-specific imprinting of the human insulin-like growth factor-II gene. Nature 371: 714-717.

Vu TH, Li T, Hoffman AR (2004). Promoter-restricted histone code, not the differentially methylated DNA regions or antisense transcripts, marks the imprinting status of IGF2R in human and mouse. Hum Mol Genet 13: 2233-2245.

Walther T, Balschun D, Voigt J-P, Fink H, Zuschratter W, Birchmeier C et al. (1998). Sustained long term potentiation and anxiety in mice lacking the Mas protooncogene. J Biol Chem 273: 11867-11873.

Wilkins JF, Haig D (2003). What good is genomic imprinting: the function of parentspecific gene expression. Nat Rev Genet 4: 359-368.

Williamson CM, Blake A, Thomas S, Beechey CV, Hancock J, Cattanach BM et al. (2013). World Wide Web Site-Mouse Imprinting Data and References-. http://www.har.mrc. ac.uk/research/genomic_imprinting/

Wolf JB, Hager R (2006). A maternal-offspring coadaptation theory for the evolution of genomic imprinting. PLOS Biol 4: e380.
Wolf JB, Hager R (2009). Selective abortion and the evolution of genomic imprinting. $J$ Evol Biol 22: 2519-2523.

Xu F, Xia W, Luo RZ, Peng H, Zhao S, Dai J et al. (2000). The human ARHI tumor suppressor gene inhibits lactation and growth in transgenic mice. Cancer Res 60: 4913-4920.

Yang Y, Li T, Vu TH, Ulaner GA, Hu JF, Hoffman AR (2003). The histone code regulating expression of the imprinted mouse Igf2r gene. Endocrinology 144: 5658-5670.

Yballe CM, Vu TH, Hoffman AR (1996). Imprinting and expression of insulin-like growth factor-II and H19 in normal breast tissue and breast tumor. J Clin Endocrinol Metab 81: 1607-1612.

Yu Y, Fujii S, Yuan J, Luo RZ, Wang L, Bao J et al. (2003). Epigenetic regulation of ARHI in breast and ovarian cancer cells. Ann NY Acad Sci 983: 268-277.

Yu Y, Xu F, Peng H, Fang X, Zhao S, Li Y et al. (1999). NOEY2 (ARHI), an imprinted putative tumor suppressor gene in ovarian and breast carcinomas. Proc Natl Acad Sci USA 96: 214-219. 